\title{
Scholars as allies in the struggle for food systems transformation
}

\author{
Charles Z. Levkoe ${ }^{1} \mathbb{D}$
}

Accepted: 30 March 2021 / Published online: 9 April 2021

(C) The Author(s), under exclusive licence to Springer Nature B.V. 2021

\begin{abstract}
Molly Anderson's 2020 Presidential Address for the Agriculture and Human Values Society, is a bold call to action that considers the scope and depth of the challenges facing global food systems. This call has particular relevance to scholars who are closely aligned with struggles for food justice and food sovereignty. In this discussion piece, I suggest additional nuance that builds and expands on Anderson's three opportunities for "pushing beyond the boundaries". First, collaborations for social and ecological change must be willing to expand predominant ideas to the varied ways that people engage with food systems (e.g., consider the role of harvesting non-domesticated foods and migrant/undocumented workers across the food chain). Second, interactions with global social movements demands grounding our work in the hearts and minds of individuals and communities while also addressing structural concerns at the levels of governance that enable and constrain food system functions. Third, food systems thinking and action must begin with our relationships to the land and its original inhabitants. The settler colonial project is integrally connected to the dominant food system that is premised on exploitation and control of land, water and people. As scholar allies, "pushing the boundaries" demands acknowledging ways that we are complicit in unjust systems and ways that we benefit from them; doing the personal work required for unlearning and relearning; being prepared to take actions that move towards more equitable and sustainable food systems; and, accepting the potential risks and material consequences that equity demands.
\end{abstract}

Keywords Ally $\cdot$ Food sovereignty $\cdot$ Food systems $\cdot$ Scholar-activist $\cdot$ Social movement

Molly Anderson's (2021) 2020 Presidential Address for the Agriculture and Human Values Society (AFHVS), Pushing Beyond the Boundaries, is an insightful and timely call to action that considers the scope and depth of the challenges facing global food systems. She points to evidence that the dominant capitalist, industrial food system benefits the powerful at the expense of people and the planet. Further, Anderson suggests that transformation demands addressing social and environmental justice through both personal and collective approaches. This call has particular relevance to scholars who are closely aligned with social movement struggles for food justice and food sovereignty. What does it mean to be an ally in this work, especially for those of us in places of relative privilege (be it from our gender, race, job security, academic freedom, etc.)? Reflecting on ways that white, male faculty engage in social justice struggles,

Charles Z. Levkoe

clevkoe@lakeheadu.ca

1 Department of Health Sciences, Lakehead University, 955 Oliver Rd, Thunder Bay, ON P7B 5E1, Canada
Patton and Bondi (2015) argue that ally work must be "ongoing, requiring continual reflection, and perseverance. It involves moving beyond words toward actions that disrupt oppressive structures and understanding one's positionality in oppression" (p. 489). Reynolds et al. (2018) suggest that blurring the lines between scholarship and activism can significantly strengthen food justice work within the academy and beyond. In my experience as a white, cisgendered male scholar-activist aligned with struggles for food systems transformation, this work has demanded building meaningful and mutually beneficial relationships, a commitment to action, and ongoing critical reflexivity throughout all aspects of my personal and professional engagements.

Anderson's Presidential Address highlights a series of challenges embedded within the dominant food system and suggests that there is much to learn from the knowledge and experiences of social movements and people at the forefront of struggles for more equitable and sustainable food futures. She considers ways that scholars and social movement actors can move beyond existing constraints towards transformation at the individual, community, and global levels. The 
main focus of her commentary are three proposed opportunities for pushing back on constraints that include international collaborations, interactions with global social movements, and anti-racist work. These opportunities provide valuable insights that suggest a significantly different direction than the one currently being charted by the dominant food system. Considering these opportunities, in relation to my own scholar-activism, living and working on the northern shores of Lake Superior, the Traditional territory of the Fort William First Nation, signatory to the Robinson Superior Treaty of 1850 (Thunder Bay, Ontario, Canada), I suggest some additional nuance that builds and expands on each of Anderson's calls to action.

First, international collaborations are essential for social and ecological change. Collaborations must be rooted within food systems but also be willing to expand ideas to incorporate the varied ways that people engage with them. For example, much of the current work identifying with food systems scholarship and movements remains agricultural-centric. Despite harvesters and gatherers playing a foundational role in the development of food sovereignty discourses, there has been little engagement with these movements (Levkoe et al. 2017). This has become evident through my own work, engaging with communities associated with a long history of harvesting non-domesticated foods. This includes hunting, harvesting and foraging of foods such as fruits, berries, wild meats and freshwater fish. According to the FAO's (2020) State of World Fisheries and Aquaculture in 2017, 17\% of all global protein consumption comes from fish. Like agriculture, fisheries have been severely impacted by corporate consolidation and technocratic management approaches focused on profit, leading to crisis-level implications for ecosystems and the communities that rely on small-scale fisheries for food and livelihoods (Sundar 2016). This has had a devastating impact on Indigenous Peoples ${ }^{1}$ who have relied on access to forest and freshwater foods, including fisheries and wild foods from time immemorial. In another example, while food movements focus on farmers' livelihoods and the impacts of agriculture on soil health, less attention has been paid to migrant and undocumented workers who provide their labour to feeding populations across the global north. Addressing the treatment and circumstances of farm workers (and workers across the food chain) but also the underlying circumstances that force people to leave their homes and families (and in many cases, their own farms) demand addressing unjust foreign policies and global relations. These enable the exploitation and impoverishment of

\footnotetext{
${ }^{1}$ I use the term "Indigenous Peoples" to refer to the diverse group of people who are the original inhabitants of specific places and maintain distinct cultures, languages, practices, institutions, and relationships with the lands.
}

certain people (and countries) so that others may prosper (Minkoff-Zern 2019; Weiler et al. 2020).

For scholars, considering transformative food systems work as part of social movements demands an internationalist perspective rooted in collaborations that cross scale, sector and place (Holt-Giménez and Shattuck 2011). To address equity and sustainability within food systems, we must consider the range of issues that contribute to inequity and address ways that power functions across geographies, even if these issues initially appear unrelated. Anderson discusses a number of inspiring efforts that demonstrate ways diverse actors (e.g., scholars, practitioners, food workers, etc.) have mobilized to address structural food systems issues-for example, the International Panel of Experts on Sustainable Food Systems (IPES-Food) ${ }^{2}$ and the Civil Society and Indigenous Peoples Mechanism ${ }^{3}$ of the Committee on World Food Security. In addition, we can look to human rights frameworks such as the Universal Declaration of Human Rights that affirms the right to food or more recent achievements such as the United Nations Declaration on the Rights of Indigenous Peoples and the Declaration on the Rights of Peasants and Other People Working in Rural Areas.

Anderson's second opportunity builds on international collaborations by focusing on interactions with global social movements. Similarly, this demands working across sectors, scales and places while being rooted in a transformative food politics as articulated through ideals of food sovereignty (Wittman et al. 2010). Beyond regional focused actions, many food movements are seizing opportunities to advocate for greater power and influence in food systems governance - that is, the relationships, rules, practices and structures through which power and control are exercised and decisions are made in respect to how food is produced/ harvested and distributed (Andrée et al. 2019; Desmarais et al. 2017). Grounding work in the hearts and minds of individuals, communities and building solidarity is at the core of most social movement efforts. Building on placebased experiences to address structural concerns at the level of policy that enable and constrain food system functions is an essential part of transformation. Scholars can play a vital role in this work by contributing knowledge and skills (and resources).

An example of these kinds of collaborations can be found in the Pan-Canadian People's Food Policy (PFP) that was led by a coalition of food systems scholars, activists, practitioners, Indigenous Peoples, workers and many others. The PFP was a collaborative initiative that took place between

\footnotetext{
${ }^{2}$ For more details on the International Panel of Experts on Sustainable Food Systems (IPES-Food), see http://www.ipes-food.org/

${ }^{3}$ For more details on the Civil Society and Indigenous Peoples Mechanism, see http://www.csm4cfs.org/
} 
2008 and 2011, to develop Canada's first and only citizen-led comprehensive food policy platform (Levkoe and Sheedy 2019). The PFP mobilized thousands of people from across food systems and beyond who were involved in place-based work to share their ideas, experiences and visions of what a more equitable and sustainable food system could look like. Considering the wealth of responses from thousands of people across the country, contributions were compiled and synthesized into a series of draft discussion papers. The PFP worked closely with a wide range of food movements to engage in an interactive process to solicit input and consensus and prioritize the proposals. This resulted in the development of a policy platform rooted in a food sovereignty framework. Beyond setting the course for food systems action in Canada, this effort led to engagements with social movements across the globe and inspired related efforts in other regions. We can take inspiration from these kinds of social movement-led initiatives and opportunities for collaborations with scholars that aim to scale up placebased efforts to have a broader and more systemic impact.

Third, Anderson points to anti-racism as an effective way of pushing beyond boundaries towards food systems transformation. This is undoubtedly an issue of utmost importance in respect to deep inequities, which that have been made even more visible by the COVID-19 pandemic. To build on this discussion, I suggest a particular consideration of strategies to address the ongoing discrimination and antagonisms towards Indigenous Peoples. For scholars, thinking about food systems must begin with our relationships to land and water, and in turn its original inhabitants. Anti-Indigenous racism and settler colonialism point to attempts at systematic erasure of Indigenous Peoples by settler populations (Wolfe 2006). Since the arrival of European settlers, Indigenous Peoples have been violently removed from their lands and forced to assimilate into the dominant settler culture (Manuel and Derrickson 2015). This includes the imposition of foreign legal systems, the theft of cultural knowledge through the residential school system, over policing, and the apprehension of children from their communities. Diverse Indigenous traditions around food have been treated with contempt by settler governments and viewed as an obstacle to colonial notions of progress and development. The settler colonial project is integrally connected to the dominant food system that is premised on exploitation and control of land, water and people.

While there is a burgeoning field of scholarship analyzing and addressing Indigenous food systems (Settee and Shukla 2020; Whyte 2018), there has been limited interrogation of the role of settler colonialism within food movements (Bohunicky et al., forthcoming). The theory and practice of Indigenous food sovereignties (along with other forms of Indigenous resistance and resurgence) suggest different kinds of relationships with land and place that acknowledge and centre Indigenous histories and support inherent rights to traditional food practices (Coté 2016; Daigle 2019; Morrison 2011). The Indigenous Food Circle (IFC) in Northwestern Ontario is an example of an Indigenous-led network using food as a tool for reconciliation and resurgence (Levkoe et al. 2019b). The IFC was established in 2016 and is structured as a partnership between Indigenous leaders in the Thunder Bay region (representing the social services, health, education, and community development sectors as well as tribal councils, elders and knowledge keepers) and a range of settler allies. Ultimately, the IFC aims to increase food self-determination and realize Indigenous food sovereignty. Scholars have played a valuable role in the IFC, working alongside community-based projects that establish meaningful relationships through food.

Each of these opportunities (and many others that have been proposed and debated) are vital to the emancipatory project of social and environmental justice and collective liberation. Nevertheless, these actions cannot be taken in isolation. Ultimately, the challenges underlying the dominant food system are systemic and structural. Considering the role of scholar-activists working with food movements, others have argued for an approach that embodies collective processes, integrative co-learning, multidirectional accountability, and critical reflexivity (Levkoe et al. 2020; Montenegro de Wit et al. 2021). As scholar allies, we need to move beyond feeling sympathetic and horrified while we observe a system that makes so many people vulnerable. Food sovereignty demands a radical praxis-not just studying and theorizing but taking action led by the work of social movements (Levkoe et al. 2019a). This involves considering what it means to do food justice and food sovereignty work and being ready to step forward and step back when required. Refusing to be complicit with dominant systems of oppression, involves recognizing that there are less risks and sacrifices for those of us who engage in this work from a place of relative privilege. Patton and Bondi (2015) write that scholars (especially white male faculty), need to situate our activism with individuals (e.g., supporting students and co-workers, adapting our teaching and research) while also working to disrupt social inequalities and challenging the status quo. As scholar allies, this demands acknowledging ways that we are complicit in unjust systems and ways that we benefit from them (directly and/or indirectly); doing the personal work required for unlearning and relearning; being prepared to take actions that move towards a more equitable and sustainable food system for all; and, accepting the potential risks and material consequences that equity demands. I stand with Molly Anderson and the many others who are willing to take this journey by pushing beyond the boundaries. 
Acknowledgements Many thanks for the invaluable feedback on this commentary from Airin Stephens, Kristin Reynolds and Colleen Hammelman and for the deep commitment to social and environmental justice work from the many scholar-activists and activist-scholars who inspire and motivate my journey.

\section{References}

Anderson, M.D. 2021. AFHVS 2020 presidential address: pushing beyond the boundaries. Agriculture and Human Values. https:// doi.org/10.1007/s10460-020-10187-6.

Andrée, P., J.K. Clark, C.Z. Levkoe, and K. Lowitt. 2019. Civil society and social movements in food system governance. New York: Taylor and Francis.

Bohunicky, M., Levkoe, C.Z., Rose, N. forthcoming. interrogating food movements confronting settler colonialism. Canadian Food Studies 6(3): 33-59.

Coté, C. 2016. "Indigenizing" food sovereignty: revitalizing Indigenous food practices and ecological knowledges in Canada and the United States. Humanities 5 (57): 1-14.

Daigle, M. 2019. Tracing the terrain of Indigenous food sovereignties. The Journal of Peasant Studies 46 (2): 297-315.

Desmarais, A.A., P. Claeys, and A. Trauger, eds. 2017. Public policies for food sovereignty: Social movements and the state. New York: Routledge.

FAO. 2020. Summary of the impacts of the COVID-19 pandemic on the fisheries and aquaculture sector: Addendum to the State of World Fisheries and Acquaculture 2020. Rome: FAO.

Holt Giménez, E., and A. Shattuck. 2011. Food crises, food regimes and food movements: Rumblings of reform or tides of transformation? The Journal of Peasant Studies 38 (1): 109-144.

Levkoe, C.Z., C. Hammelman, K. Reynolds, X. Brown, M.J. Chappell, R. Salvador, and B. Wheeler. 2020. Scholar-activist perspectives on radical food geography: Collaborating through food justice and food sovereignty praxis. Human Geography 13 (3): 293-304.

Levkoe, C.Z., J. Brem-Wilson, and C.R. Anderson. 2019a. People, power, change: Three pillars of a food sovereignty research praxis. The Journal of Peasant Studies 46 (7): 1389-1412.

Levkoe, C., L. Ray, and J. Mclaughlin. 2019b. The Indigenous food circle: Reconciliation and resurgence through food in northwestern Ontario. Journal of Agriculture, Food Systems, and Community Development 9: 101-114.

Levkoe, C.Z., and A. Sheedy. 2019. A people-centred approach to food policy making: Essons from Canada's People's Food Policy project. Journal of Hunger and Environmental Nutrition 14 (3): 318-338.

Levkoe, C.Z., K. Lowitt, and C. Nelson. 2017. "Fish as food": Exploring a food sovereignty approach to small-scale fisheries. Marine Policy 85: 65-70.
Manuel, A., and G.C.R.M. Derrickson. 2015. Unsettling Canada: A national wake-up call. Toronto: Between the Lines.

Minkoff-Zern, L.A. 2019. The new American farmer: immigration, race, and the struggle for sustainability. Cambridge: MIT Press.

Montenegro de Wit, M., A. Shattuck, A. Iles, G. Graddy-Lovelace, A. Roman-Alcalá, and M.J. Chappell. 2021. Operating principles for collective scholar-activism: Early insights from the Agroecology Research-Action Collective. Journal of Agriculture, Food Systems, and Community Development 10 (2): 1-19.

Morrison, D. 2011. Indigenous food sovereignty: A model for social learning. In Food sovereignty in Canada: Creating just and sustainable food systems, ed. H. Wittman, A.A. Desmarais, and N. Wiebe, 97-113. Halifax, NS: Fernwood.

Patton, L.D., and S. Bondi. 2015. Nice white men or social justice allies? Using critical race theory to examine how white male faculty and administrators engage in ally work. Race, Ethnicity, and Education 18 (4): 488-514.

Reynolds, K., D. Block, and K. Bradley. 2018. Food justice scholaractivism and activist-scholarship. ACME An International Journal for Critical Geographies 17 (4): 988-998.

Settee, P., and S. Shukla, eds. 2020. Indigenous food systems: Concepts, cases, and conversations. Toronto: Canadian Scholars.

Sundar, A. (2016). The food system in the fisheries: crisis and alternatives. In Critical Perspectives in Food Studies (Second Edition), ed. M. Koc, J. Sumner, and A. Winson, 169-184. Toronto: Oxford.

Weiler, A.M., K. Sexsmith, and L.A. Mikoff-Zern. 2020. Parallel precarity: A comparison of US and Canadian agricultural guestworker programs. The International Journal of Sociology of Agriculture and Food 26 (2): 143-163.

Whyte, K. 2018. Food sovereignty, justice and Indigenous Peoples: An essay on settler colonialism and collective continuance. In The Oxford handbook of food ethics, ed. A. Barnhill, M. Budolfson, and T. Doggett, 345-366. New York: Oxford University Press.

Wittman, H., A. Desmarais, and N. Wiebe. 2010. Food sovereignty: Reconnecting food, nature and community. Halifax: Fernwood.

Wolfe, P. 2006. Settler colonialism and the elimination of the native. Journal of Genocide Research 8 (4): 387-409.

Publisher's Note Springer Nature remains neutral with regard to jurisdictional claims in published maps and institutional affiliations.

Charles Z. Levkoe is the Canada Research Chair in Sustainable Food Systems and an Associate Professor in the Department of Health Sciences at Lakehead University. Charles' community engaged research uses a food systems lens to explore connections between social justice, ecological regeneration, regional economies and democratic engagement. Learn more about his work at https://foodsystems.lakeheadu.ca. 